\title{
«Rhome, Rumon, Ruma». Una aproximación global al origen del nombre de Roma
}

\section{"RHOME, RUMON, RUMA". An approach to the origins of the name "Rome"}

\author{
LUIS CASquillo Fumanal \\ Liceo Español «Cervantes». Roma
}

\begin{abstract}
RESUMEN ABSTRACT
La etimología del nombre de Roma es todavía un problema abierto. Quedan en pie las teorías que hacen derivar Roma

del etrusco Rumon, "río», o del itálico Ruma, "ubre, colina». Pasada ya la fiebre etruscológica, ahora que el relato tradicional de la fundación de Roma por Rómulo adquiere nuevo vigor en la escuela arqueológica italiana de Andrea Carandini, resulta oportuna la reivindicación de la etimología de Roma a partir del itálico Ruma, teniendo en cuenta el conjunto de nuevos datos - sobre todo antropológicos-que contribuyen a dar valor a esta teoría.

PALABRAS CLAVE:

Rhome, Rumon, Siete Colinas, Lupercal, Ruminal, quasi-totemismo, Ruma, Roma.

The etimology of the name Rome is yet an open probleme. They are still standing theories that make derive Rome from the etruscan word Rumon, "river", or from the italic word Ruma, «nipple, hill».

Nowadays, when the etruscological fever is gone and the traditional story of the foundation of Rome by Romulus obtains a new consistency in the italian archaeological school of Andrea Carandini, it turns very oportune the reivindication of the etimology of Rome from italic Ruma, bearing in mind the joint of new dates

- especially anthropological dates— that contribute to value this theory.

KEYWORDS:

Rhome, Rumon, Seven Hills, Lupercal,
\end{abstract}


Hoy día son ya muy pocos seguramente los que dudan de la importancia de ponerse la pregunta sobre el origen del nombre de Roma. ${ }^{1}$ ¿Puede existir una respuesta «verdadera» a la pregunta sobre el origen del nombre de Roma? Sobre el nombre de la Ciudad Eterna ha habido tres interpretaciones sucesivas, que se han ido presentando a lo largo de la arqueología histórica en grado ascendente de verosimilitud. 1) Según la que llamaremos interpretación (o teoría) helenística, el nombre Roma procede de Rhomê, la mujer troyana que llegó al Lacio con Eneas; 2) según la interpretación (o teoría) que llamaremos etrusca, Roma es una corrupción de Rumon, el primitivo nombre etrusco del río Tíber; y 3) según la interpretación que llamaremos itálica, Roma viene de Ruma, que en la primitiva lengua de los oscos significaba «ubre» o "colina».

Al abordar el estudio del origen del nombre de Roma, no podemos aspirar más que a aproximarnos con humildad a los datos sin colmar la aspiración de saber actualmente la verdad. Renunciando, pues, a alcanzar una verdad total acerca del nombre Roma, me limitaré a hacer un estudio global de verosimilitud de cada una de las tres teorías existentes. Estudiaré toda la clase de hechos históricos (o filológicos) -los posibles «enunciados verdaderos» de Karl Popper- relacionados con cada de las tres teorías, tratando de saber cuál de ellas está más rodeada de «verdad» y, por lo tanto, es más verosímil, más probable. Por eso, este estudio va más allá de un mero análisis etimológico del nombre de Roma y se extiende a todos los aspectos relacionados directamente con la fundación de la Urbe y atribución de un nombre a la misma.

El orden en que estudiaremos las teorías sobre el origen de Roma es el que nos ha parecido como orden creciente de verosimilitud: 1) Roma $<$ Rhome, «fuerza», 2) Roma < Rumon, «río», y 3) Roma < Ruma, «colina-ubre». Mantienen su vigencia la teoría Roma $<$ Ruma (ubre,colina) y la teoría Roma $<$ Rumon (río). Al final de este estudio, pretendo haber llegado a la conclusión de que Ruma es ya la etimología más verosímil de Roma. Si aun así me siento obligado a exponer brevemente las restantes teorías es porque, como hemos dicho, la mayor probabilidad de la última - Ruma - resulta de la contrastación con las anteriores; y porque, en todo caso, la mayor probabilidad de una teoría emerge de la mayor «falsabilidad» de las anteriores. En efecto, «aproximación a la verdad» en la metodología popperiana no es otra cosa que alejarse de las teorías ya comprobadamente «falsables».

1 Hay que reconocer, sin embargo, que hasta el final de la década de los sesenta algún autor era escéptico sobre la utilidad de tal investigación: «Perciò è inutile speculare sulla etimologia di Roma. E a quanto maggior ragione per la brevità e semplicità della forma, poiché non sappiamo nemmeno a quale strato linguistico appartenga questo toponimo» (E. Peruzzi, Origini di Roma (I). La famiglia. Firenze, Valmartina editore,1970, p. 17). Pero el propio Peruzzi haciendo remontar la etimología de Roma a un estadio «forse preromuleo» (ibid. n. 1) dejaba abierta una puerta a la investigación, por la que otros no han vacilado en adentrarse. 


\section{LA INTERPRETACIÓN HELENÍSTICA: RHOME}

Según esta interpretación, la más antigua —pero a la vez la más débil, según veremos-, el nombre de Roma procede de Rhome, la esposa troyana de Eneas, el príncipe troyano huído del saqueo de Troya. La primera noticia sobre esta relación toponímica se remonta al historiador griego Helánico de Lesbos en el s. v a.C., quien dice que «Eneas llegó a Italia desde el país de los molosos y junto a Odiseo fundó la Urbe, y la llamó a partir del nombre de Rhome» (D.C. 1.72.2). Rhome, como heroína epónima de Roma, es una probable y necesaria creación literaria de Helánico: Eneas (que actúa como fundador con Odiseo) no le sirve a tal fin, pues de su nombre resulta imposible derivar el de Roma.

La interpretación griega del nombre de Roma es de carácter meramente legendario: La figura de Rhome (y todas las otras matrices de filiación para un supuesto Rhomos) carecen de fundamento histórico. Sólo se basan en la práctica de los historiadores helénicos - sobre todo helenísticos- de dar origen griego a las grandes ciudades de su tiempo. La conclusión de que Rhome, epónima y «co-fundadora» de Roma con Eneas, es una típica creación griega la confirma ya su falta de exclusividad, pues tuvo que convivir con otros muchos personajes a quienes se concedía la misma función. La misma figura de Eneas, emigrante a Italia y, en concreto al Lacio, ha perdido toda base real en el conjunto de las fuentes históricas para el estudio del Lacio primitivo: ni la arqueología ni el fondo historiográfico aportan ninguna confirmación documental válida de la presencia de Eneas ( $\mathrm{y}$ a fortiori de Rhome) en el relato fundacional de Roma. La ciencia griega de la antigüedad primitiva (la archaeologia en sentido griego) no rehusó transformar relatos y figuras legendarias en personajes y acontecimientos históricos: ${ }^{2}$ Eso significa que aun los fundadores de ciudades no helénicas, como Roma, ineludiblemente habían de ser de procedencia griega 0 , al menos, pertenecer, como los troyanos, al área literaria griega. Tal es el caso de Eneas y de su esposa Rhome, como epónima de la saga de Rhomos-Rómulo, el fundador de Roma.

A esa primera objeción había que añadir la distancia cronológica entre Rhome y la fundación de Roma. A partir de Eratóstenes (hacia el 300 a.C.) , que asignaba a la caída de Troya una fecha tan temprana como el año 1184 a.C se consolidó la cronología mítica, y los anales de los Pontífices romanos fijaron-según Varrón- el año 753 a.C. como fecha de la fundación de Roma. La constatación misma por parte de los historiadores griegos de ambas fechas y la distancia entre ambos acontecimientos hacía imposible atribuir a un troyano o hijo de troyana la fundación de Roma. Y, por tanto el nombre Rhome, esposa de Eneas, quedaba excluído como posible origen patronímico del fundador de la Urbe.

Con el crecimiento progresivo del gap temporal entre la guerra de Troya (1184 a.C.) y la fundación de Roma (753 a.C.) según la cronología mítica, ni Eneas ni su

2 Ver E.J. Bickerman, «Origines gentium» CPh 47, 1952 pp.65-81. 
esposa Rhome toman ya parte directa en la fundación de Roma. En consecuencia, se hizo inevitable para la primitiva evolución de esta teoría, aún en manos de historiadores griegos, que la adjudicación directa de nombre a la ciudad pasara de Rhome a Rhomos (o apelativo similar), el legendario hijo de la troyana y de Eneas. Evidentemente esto no era suficiente y fue necesario retrotraer en el tiempo la acción de los fundadores, hasta llegar al relato tradicional en que, unos cuatro siglos después de la llegada de Eneas al Lacio, Rómulo, ya no hijo de Eneas, sino de Marte y Rhea Silvia, da su nombre a la ciudad al batir a Remo en su lucha por auspicios favorables para la nueva ciudad de Roma. La versión canónica se encontraba - parece ser- en «los Orígenes» de Catón el Viejo, obra después desaparecida.

Aunque la saga intermedia entre Rhome y Rhomos fue creciendo casi indefinidamente, era imprescindible, para mantener las raíces troyanas de Roma, retrotraer el nombre del fundador, Rómulo (<Rhomos), hasta los orígenes y hacerlo derivado de Rhome. Sorprendentemente el primer Rhomos, el hijo de Eneas, identificado con el futuro Rómulo, tuvo lo que podríamos llamar un nombre «matronímico» en lugar del patronímico Enéada que según la norma le habría correspondido. Así, pues, Rhomos (o Rómulo) habría heredado de su madre Rhome el nombre de familia, algo en sí mismo inverosímil en una edad eminentemente patriarcal.

$\mathrm{Ni}$ la cultura griega ni la latina admitían en tiempos de Eneas una trasmisión matrilineal del nombre: Eneas es un Anquisíada, «hijo de Aquises» - y en línea remota Dardánida, es decir «descendiente de Dárdano». Y Tito Livio al elaborar la genealogía de los legendarios reyes latinos que van desde Eneas, rey de Lavinio, hasta Numítor, el rey de Alba Longa, padre de Rómulo, elimina el inverosímil matronímico Rhomos, hijo de Rhome, sustituyendo el nombre del hijo de Eneas, sea quien haya sido su madre, por el de Ascanio-Julo, como ya hiciera Virgilio en beneficio de la dinastía Julia (ib. I, 3, 2-3; cf. VERG. Aen. 1.288). De esa forma, el origen griego-troyano del nombre de Roma quedaba eliminado de la leyenda. Era más probable que el nombre Rómulo proviniera del nombre de la ciudad y no al revés: Roma no procede de Rómulo, sino más bien de Roma procede Rómulo, que probablemente no significa otra cosa que el «Romano», es decir, el romano por excelencia.

La extraordinaria fuerza militar de la naciente Roma bajo la monarquía etrusca, ya desde finales del s. vi a.C. en la gran época de los Tarquinios, debió sugerir a los historiadores helénicos la asociación del nombre Roma con la noción griega de fortaleza (Рळ $\mu \eta$, «fuerza», de la misma raíz indoeuropea que el latín robur, robustus). La prosodia latina del nombre de Rôma permitía la aproximación etimológica a la troyana Rhôme. ${ }^{3}$ Igualmente la derrota de las falanges del macedonio Pirro

\footnotetext{
3 A esta etimología se siguen acogiendo los que aún consideran válida la tesis de que el nombre de Roma deriva de Rhome: «Wiseman...crede sorprendentemente...che il nome originario di Roma, città creata a suo avviso alla fine del VII secolo a.C., derivi da rhome (=forza, in greco)» (Andrea Carandini, Archeologia del mito, Einaudi, Torino 2002, p. 125).
} 
frente a las legiones romanas en el año 275 a.C. levantó toda una oleada de admiración por Roma entre los historiadores griegos: Jerónimo de Cardia y Timeo de Tauromenio fueron los primeros que la narraron la guerra de Roma contra los griegos de la Magna Grecia comandados por Pirro, añadiendo como un prólogo la historia de la fundación de la ciudad por Rómulo, hijo de Eneas. Por un poema de Licofronte titulado Alejandro sabemos cómo contaba Timeo la fundación de Roma. En su obra ya no interviene Eneas directamente en la fundación de Roma; aparece solamente como fundador de treinta ciudadades latinas, tantas como lechones parió la cerda que el héroe trajo consigo de Troya (cuya estatua de bronce Timeo pudo contemplar en Lavinio), y como depositario en la nueva tierra de los dioses penates que salvó de la quema de Troya. La obra de Timeo fue la que permitió enlazar los hechos romanos con la leyenda troyana. Partiendo de ahí es posible decir que «Pirro fue el primero en hacer a los romanos sentirse troyanos» ${ }^{4}$.

Podemos, pues, dar como cierto que la tradición latina entendió su raíz troyana como un signo de oposición a Grecia: Roma, la nueva Troya, se consagraba así como la vengadora secular contra los reinos de los descendientes de los campeones aqueos (ver T.J.Cornell, ibid.). Pero esa exaltación de unas fingidas raíces troyanas de Roma queda reducida a un hecho tardío, que nada prueba sobre el origen mismo de la ciudad y de su nombre propio.

\section{LA INTERPRETACIÓN ETRUSCA: RUMON}

La segunda interpretación histórica del nombre de Roma lo hace derivar de la palabra etrusca rumon, que significa «río». Esta teoría presupone que Rumon debió ser el nombre del río que pasa por Roma antes de llamarse Tíber, y que del río pasó el nombre a la ciudad. Fue propuesta por Corssen y Guidi. Con cierta vacilación Gaetano de Sanctis fue el primero en acogerla en su obra Storia dei Romani (Torino 1907, p.187, p.190, donde se contiene la bibliografía al respecto). Los Tarquinos habrían fundado la ciudad con el objeto de asegurar mediante una plaza fuerte el vado natural del río Tíber que existió junto a la isla Tiberina: Esa asociación natural fortificación-río sería la que justifica que Roma recibiera un nombre tan genérico como el de «ciudad del río».

El crédito creciente de esta teoría estuvo ligado a la crisis que a partir de los años 40 del pasado siglo Xx afectó al relato tradicional de la fundación de la ciudad de Roma por Rómulo.en el siglo vIII a.C. Las aportaciones arqueológicas de Gjerstad (1950) y las conclusiones de la historiografía romana calificada de «hipercrítica», desde la Storia di Roma de Ettore Pais, a finales del siglo XIX hasta la obra de Poucet ya en la segunda mitad del pasado siglo, llevaron a una consideración extrema: Toda la época pre-etrusca de Roma quedó reducida a la calificación de eta-

4 T.J.Cornell, The Beginnings of Rome. Routledge, London and N.Y. 1995 (trad.español. de Teófilo de Lozoya: Crítica. Mondadori y Grijalbo ed., Barcelona 1999, p.90. 
pa meramente legendaria. En todo caso, a nivel histórico la Roma pre-etrusca sólo podía hallarse a un nivel pre-urbano o todo lo demás proto-urbano, pero nunca urbano. La ciudad en sentido propio - como infraestructura urbana (urbs), y como agregación de ciudadanos (coetus civium o civitas) — sólo resultó aceptable como fundación etrusca, negándose tal carácter al escaso nivel de civilización que los latinos habían conseguido durante el siglo vIII y la primera mitad del s. VII a.C. Y ello porque el propio nacimiento de la ciudad se contempla unido a la superación del viejo estatuto de las gentes latinas, que hasta el momento sólo habrían concedido a su rey (mero rey sagrado: rex sacrorum), única instancia central unitaria, el valor de jefe de una liga sagrada de mutua defensa, pero negándole a la vez todo poder sobre su marco jurídico de convivencia (statuta gentis). La llegada a Roma de los etruscos habría supuesto un cambio sustancial en la organización familiar. Los etruscos trataron de imponer en Roma un poder central —la Monarquía- destinado a subordinar a sí cualquier otro tipo de poder. Para lograr su objetivo, los etruscos se apoyaron en la plebe, cuya característica social era precisamente el no estar organizada en «gentes». Y los etruscos combatieron el sistema de «gentes» fortaleciendo la familia y, por ende, a la plebe. En esta lucha del poder centrípeto de los estrucos contra el poder centrífugo de las "gentes» latinas es donde se pone la aparición del Estado, de la ciudad-estado, es decir (¿), la fundación de Roma. Tal orientación perdura hasta la actualidad aun en los que, apartados de los excesos hipercríticos, mantienen una mera postura crítica en relación a la existencia de una propiamente dicha ciudad de Roma anterior a los etruscos —una posición que sorprendentemente tienden a enraizar en la tradición misma ${ }^{5}$.

Con ese punto de partida la Roma pre-etrusca queda borrada de la historia y el nacimiento de Roma es incorporado al ámbito de la etruscología. El nombre de Roma pasa a ser de origen etrusco con el mismo derecho con que el estudio de los orígenes de Roma «tendía a convertirse en un dominio anejo y provincial de una etruscología en pleno auge». ${ }^{6}$ Sin mucha discusión filológica, la asociación del nombre Roma a una base etrusca fue aceptada aun por los Diccionarios Etimológicos más prestigiosos de mitad del siglo pasado: «Roma, nombre de la capital del Lacio, de origen quizás etrusco» (Ernout-Meillet, s.v.).

Esta teoría del origen etrusco del nombre de Roma choca también con sólidas objeciones. La primera objeción es la ausencia de fuentes históricas antiguas que confirmen la atribución del nombre Rumon al río de Roma. Sólo el comentador Servio (Serv. A. 8. 63 y 90), a propósito de la llegada de Eneas junto al río de la futura Roma, transmite la insólita noticia de que el Tíber se llamó en un tiempo Rumon. Aparte de Servio - malus testis unus testis-, nadie llama nunca Rumon al río de Roma. A decir verdad, la única denominación diversa del río Tíber que se conoce

5 «La urbs romana es consecuencia de la dominación etrusca y, en ello, coinciden los testimonios arqueológicos, las instituciones y la propia tradición historiográfica» (J.M. Roldán, La república romana, ed. Cátedra, Madrid 1995, p. 52).

6 Alexandre Grandazzi, La fondation de Rome. Reflexión sur I'histoire. Les Belles Lettres, Paris 1991: trad.it. Ed. Laterza, 1993, p.200 
es la de Albula, nombre que atestiguan Tito Livio y Virgilio (LIV. 1.3.8 y VERG. Aen. 8. 330-332). Imposible atribuir al río de Roma un antiguo nombre, anterior a Tíber, que no sea Albula, palabra en todo caso de clara etimología latina. ¿Será , entonces, que los etruscos, a pesar de que el río de la futura Roma tenía ya un nombre — «Álbula» primero, y Tíber más tarde-, decidieron ignorarlo y llamar a la nueva ciudad con un nombre tan genérico como «ciudad del río»?

La segunda objeción es la ilegitimidad lógica de la conclusión: ritual etrusco > ciudad etrusca. Parece inobjetable que el ritual con que se fundó Roma fue de origen etrusco. En eso coinciden todas las fuentes antiguas, las etruscas y las romanas. Las raíces etruscas del ritual de fundación son comprensibles: En un tiempo en que Etruria era la región urbanísticamente más desarrollada de la península itálica los romanos copiaron el ritual de fundación etrusco y lo aplicaron a sus propias fundaciones: En relación a las colonias romanas el hecho está documentado a partir del siglo III a.C.: ninguna colonia romana fue fundada antes de esa época. Pero es evidente que los latinos pudieron copiar ya en época romúlea para fundar y denominar su propia ciudad el mismo ritual etrusco que, sin ser suyo, copiaron más tarde para sus propias colonias. De hecho, desde Catón y Ennio, los partidarios del relato tradicional de la fundación por Rómulo de una Roma con su propio nombre latino nunca recelaron del carácter etrusco del rito fundacional (ver Varrón, etc.).

Por su parte Andrea Carandini establece una distinción clara entre diversos ritos de «inauguración»: Si bien el trazado por el arado del sulcus primigenius, el surco por el que habían de discurrir las murallas de la ciudad y el arte de adivinación por medio del examen de las vísceras de la víctima (el arte haruspicina) es una indudable herencia etrusca, el auspicium y el arte de los augurios en general no eran de origen etrusco (cfr. CIC. N.D. 2.11; Div. 1.3; 2.70 y 2.75 ss.). Y es precisamente el auspicio o consulta adivinatoria del vuelo de las aves el ritual en el que Rómulo y Remo dirimen su disputa en el rito fundacional de Roma : «No tenemos por qué aceptar la leyenda piadosa romana según la cual Rómulo fundó la ciudad siguiendo el protocolo sagrado previsto por los sacerdotes etruscos». ${ }^{7} \mathrm{En}$ todo caso hay que dejar asentado que, aunque el ritual hubiera sido etrusco, eso no implicaba que la ciudad fundada fuera creación etrusca.

A eso se añade una nueva objeción: La ilegitimidad de imponer nuestro modelo actual de ciudad al concepto de ciudad antigua. Los historiadores que vieron como inevitable la consideración de Roma, ciudad, como una fundación etrusca, y abrieron así las puertas a la teoría de Roma como una derivación de Rumon, tenían un concepto preciso de ciudad, un concepto que podríamos llamar contemporáneo y que está basado en dos pilares: en lo político la ciudad se define por un

7 A.Carandini, en Andrea Carandini e Rosanna Cappelli (editori), Roma. Romolo, Remo e la fondazione della città. Roma Museo Nazionale. Terme di Diocleziano. 28 giugno-29 ottobre 2000. Ed. Electa. Ministero per i Beni e le Attività Culturali. Soprintendenza Archeologica di Roma, p. 202; cfr. Plu. Rom. 11.1 
poder centralizado, en lo urbanístico la ciudad se define por unas infraestructuras precisas (alcantarillado, hormigón, ladrillo y/o piedra). Pero los antiguos entendían la ciudad no desde un punto de vista urbanístico, sino desde una consideración sobre todo jurídica: la ciudad se define como una congregación de hombres libres.

Con nuevos criterios la escuela italiana de Carandini, avalada por sus recientes descubrimientos en el Palatino, ha restaurado la imagen tradicional de Rómulo, fundador de la Urbe, y ha creído legítimo retomar la cronología tradicional del s. VIII a.C. para el inicio de la época urbana de Roma: «Una ciudad de cabañas, con murallas de arcilla y calles de gravilla, y sin embargo una ciudad». ${ }^{8}$

Y, como factor decisivo, alimentando todas las objeciones que hemos enunciado, está el creciente descrédito del mito de la «Roma etrusca». Ni conquista etrusca, ni irrupción incontenida de los etruscos en Roma: El dominio de los etruscos sobre Roma se ha tendido a explicar a partir de una superioridad técnica concretada en ámbitos tan vitales como la arquitectura. El perfeccionamiento arquitectónico de Roma, su emblellecimiento, es un fenómeno que alcanza en la época de los Tarquinios unas proporciones inusitadas. Pero eso, ¿qué otra cosa puede probar sino que los romanos bajo la monarquía de los Tarquinos estaban capacitados para contratar a los mejores artesanos de su época, fueran éstos -o no- estruscos? Los etruscos no habrían sido los fundadores de Roma, sino un elemento más, si bien destacado, de la composición ciudadana que contribuyó al extraordinario desarrollo de Roma. Los propios Tarquinos (si hemos de creer a la tradición analística) eran en Tarquinia unos etruscos de origen griego.

Admitamos que el influjo cultural etrusco sobre Roma desde el momento mismo de la fundación pudo superar con mucho al de otros elementos de la población. El influjo cultural etrusco sobre Roma no cesó ni siquiera con la caída de la monarquía etrusca. En resumen, si la Urbe estuvo siempre abierta al influjo de los etruscos, no es seguro que nunca estuviera dominada por ellos... »Roma no fue nunca una ciudad etrusca» (Tim J.Cornell, $1995<1999>$, p.207; ver también Jorge Mtz.-Pinna, Los orígenes de Roma. Madrid, ed. Síntesis, 1999, p.198). Y, como es lógico pensar, una ciudad que no era etrusca no es probable que diera a su río un nombre etrusco (Rumon), ni que ella misma llevara un nombre etrusco.

\section{LA INTERPRETACIÓN ITÁLICA: RUMA}

La teoría más reciente - con perspectivas de encontrar apoyos suficienteses la que hace derivar el nombre de Roma del itálico Ruma, palabra documentada en osco con el significado de «ubre» y «colina». La tesis fue propuesta entre otros por L.Pareti, (Storia di Roma e del mondo Romano I, Torino 1952, p.265). Y tiene buen soporte etimológico en la palabra latina rûmis, "ubre», según se puede

8 P. Carafa, «l contesti archeologici dell'età romulea», en A.Carandini e R.Cappelli (editori), 2000, p. 72 
comprobar en los diccionarios etimológicos latinos, por ejemplo en Ernout-Meillet (s.v.), quien no obstante se inclina por el origen etrusco de la palabra Roma, como ya hemos indicado más arriba. Esta interpretación etimológica del nombre de Roma encontró muy pronto eco favorable incluso en la literatura periodística italiana. ${ }^{9}$

La derivación del nombre de Roma a partir del itálico Ruma se hace más verosímil en tanto gana predicamento la hipótesis de una fundación muy antigua de Roma, en época pre-etrusca; y en tanto cuanto Rómulo, o quienquiera fuese el fundador de Roma a quien se atribuye la saga legendaria de Rómulo, fuese un personaje indígena y no un emigrado de Grecia o de Etruria.

Que la saga de Rómulo puede haber tenido origen en un estadio muy antiguo, independiente de la persona histórica del fundador y del valor histórico de su propio contenido, empieza a parecer cada día más verosímil a partir de los últimos estudios de la escuela arqueológica italiana. A pesar del intento de hacer demostrable un origen griego o etrusco de la figura y del nombre de Rómulo, no existen razones para volver la mirada a Grecia ni a Etruria: Toda la leyenda primitiva de Rómulo se desenvuelve en ambiente itálico, así como son latinos los testimonios más antiguos: Aunque esta interpretación - que «renueva» y a la vez «corrige» la versión del relato tradicional-, fue relanzada por Jean Bremmer (que fechó la formación del mito de Rómulo en los inicios del siglo vı a.C.), ha sido realmente impulsada por la escuela italiana de arqueología , y muy en concreto por Andrea Carandini desde que en 1985 fue encargado por la Sovrintendenza Archeologica di Roma de abrir excavaciones en la zona del Palatino. El descubrimiento de los cimientos de un muro fundacional que ciñe el perímetro exclusivo del antiguo Germal-Palatual, cuya existencia remonta sin duda a la segunda mitad del s. vIII a.C., ha permitido verificar casi plenamente la cronología del relato canónico. Apoyado en el valor concluyente de tal dato arqueológico, A.Carandini no duda en hacer remontar la fundación de Roma a una fecha situada alrededor del 730 a.C.; e interpreta la historia de Rómulo, es decir, el nacimiento de los gemelos, su abandono en el río, la intervención de la loba, y todo lo demás, como un mito popular de raíz universal, pero oficialmente reconocido y desarrollado en torno al fundador (quienquiera que él fuese - «históricamente» hablando-), y gestado contemporáneamente a los hechos o inmediatamente después de ellos (ver Cornell, en A.Carandini, 2001,p. 47).

Esta teoría tiene a su favor todo un conjunto de nombres y un conglomerado de datos legendarios e históricos conectados a tales nombres: En todos esos documentos o, como diría K.Popper, «enunciados» relativos a la fundación de la Urbe y a la leyenda de su fundador (sean testimonios historiográficos o arqueológicos)

9 «Nell'antica lingua degli Oschi, «Ruma» si interpreta «colle», oppure «zinna», in italiano «tetta». E, forse, da «Ruma, anziché da «Rumon», trasse il nome la città. La dea Ruma (sic, por «Rumina»), una zinnona indigena, protettrice dei lattanti e degli armenti, aveva un sacello in riva al fiume in fondo al Campo Boario, presso un fico detto appunto «ruminale». II fico della zinna, quindi, se l'aggettivo derivasse da «ruma»... (MAGNI Luigi, I sette re di Roma, ed. Newton, Roma 1997, p. 9). 
es constante la presencia de algún aspecto ligado al binomio «ubres=colinas» $y$, por lo tanto, al nombre mismo de Roma y a la hipotética Ruma. Relacionados íntimamente con Roma<Ruma aparecen elementos topográficos $(A)$, elementos míticos (B), elementos gentilicios o étnicos (C) y elementos lingüísticos (D) siempre presentes en la más primigenia historia de Roma, como los siguientes:

\section{A) Elementos topográficos}

\section{Las «siete Colinas» (rumae)}

La característica geográfica del territorio de la ciudad es su configuración en siete colinas. Son las legendarias «Siete Colinas» de Roma (Quirinal, Viminal, Esquilino, Celio, Aventino, Palatino y Capitolio). Pero la relación del nombre de Roma con la configuración topográfica del territorio está ya documentada en la denominación técnica de Septimontium que se dio al primitivo synoecismo anterior a la ciudad: estaba formado por los montes Germal, Palatual, Velia, Celio, Fagutal, Opio y Cispio.

Era coherente que la nueva ciudad tomara un nombre extraído del rasgo geográfico que más fuertemente chocaba al viajero que se acercaba al hábitat de las colinas.

Roma pudo ser en principio la ciudad de las colinas o, dicho en el argot quasitotémico del Lacio primitivo, la ciudad de las «tetas», Ruma. En el territorio de Roma se pueden contar más de siete colinas. El número siete pudo imponerse meramente en base a su sentido proverbial (siete sabios de Grecia, siete maravillas del mundo, siete diosas esposas de Zeus...). Decir siete podría ser sinónimo de decir multiplicidad: Roma fue la ciudad de las siete colinas, como fue la de los siete reyes... En realidad el número de siete colinas resulta de un trabajo de reelaboración del dato topográfico. A esta conclusión se puede llegar tanto en el caso del Septimontium, como en el caso de la ciudad de las Siete Colinas. El criterio en la individuación de las colinas es arbitrario, como demuestra el hecho de que en ambos caso se proceda de forma inversa.

En el caso del Septimontium se había procedido por disgregación: El Palatino, que en época histórica siempre dio impresión de unidad, cuenta como dos montes (el Germal o lado oeste, y el Palatual o lado este). Además se disgrega del Palatino y se cuenta aparte el monte Velia - actual cota del arco de Tito-, que (aunque después será brutalmente excluído del Palatino inaugurado por Rómulo) formaba parte natural de él («eran entonces dos montes gemelos», Carandini, 2000, p.137): De hecho ningún visitante que desde el arco de Tito penetre en el Palatino notará un cambio de cota, aparte de una suave pendiente. El Esquilino, cuenta como tres montes (Fagutal, Oppio y Cispio). Aquí el único criterio lógico pareció ser el hacer valer como siete montes, «muchos montes», el conjunto pre-urbano a que entonces se reducía la futura Roma: Palatino, Esquilino, Velia y Celio. Visto con otro criterio, tal conjunto de montes podría haber contado como un Quatrimontium. En el caso de las Siete Colinas se procede por exclusión y por agregación: En primer lu- 
gar se excluye de la lista de Siete Colinas al monte Velia, gemelo del Palatino, que en la anterior vía de disgregación había contado aparte en el ritual del Septimontium. Por otro lado, es evidente que el relieve del Esquilino puede dar la apariencia topográfica de tres montes diversos (ver la maqueta de Lanciani en el Museo de la Civiltà Romana): De hecho la toponimia urbana de Roma conserva bien destacados los nombres de Fagutal, Oppio y Cispio. La reducción a una única colina es resultado de una clara intención de reelaboración de los datos del Septimontium. El hecho es más evidente en el caso del Aventino, que figura en la lista como una sola colina, aun cuando la distinción entre Aventino y Pequeño Aventino es topográficamente nítida. ${ }^{10}$ Este segundo Aventino está literariamente omnipresente, al menos a partir de Ennio (cfr. Ennio, Ann. I, 45, 3 y 7). De acuerdo con Carandini, Rómulo tomó los asupicios para la fundación de Roma desde el Aventino (grande), mientras que Remo «toma los auspicios, en el mismo día, pero desde otro templum sobre el Aventino (piccolo), sede de los Remoria» (Carandini, 2000, p.119). No es factible pensar que la causa de que el Pequeño Aventino fuera excluído de número de las Siete Colinas consiste nada más en que permaneció deshabitado, a causa de su mala reputación augural: Por tal razón hubiera sido excluido también el Aventino (grande). ${ }^{11}$

Así queda explicada la voluntad de describir y denominar la ciudad en base a sus muchas (=siete) colinas, como las ubres múltiples de una loba. La base arbitraria y el contenido cultual-cultural del número 7 queda comprobado también en el número de los reyes de Roma: La tradición fijaba su número en «siete». Pero a la historiografía contemporánea no escapa la sospecha de que el número podría haber sido diverso: Tito Tacio, Aulo Vibenna y quizás el mismo Bruto podrían haber engrosado ese número (Grandazzi, 1991; a propósito de Tito Tacio, ver ya De Sanctis 1907, p. 222).

Establecido el hecho de la naturaleza arbitraria de la clasificación de Roma en siete colinas, sobre la base de la voluntad primitiva de caracterizar la ciudad por su topografía similar a las ubres de una hembra ferina, ${ }^{12}$ nos queda estudiar por qué en el caso de la Urbe la elección recayó sobre una loba, y la mutua interdependencia de ambos hechos.

10 «A oriente, tramite una sella, (la collina del Aventino) è unita, a un'ulteriore sommità, il cui nome antico ci è ignoto, ma che viene in genere chiamato Piccolo Aventino» (F.Coarelli, Roma. Mondadori, Milano 1974, p.318).

11 «Ma l'Aventino, monte che prende el nome dalle aves, non fa parte né farà parte (fino a Claudio) dell'abitato nel sito di Roma e, svolta la sua funzione di sede degli auspici e degli auguri primordiali, perderà poi per sempre questa sua caratteristica, per cui apparirà piuttosto come un luogo marginale che come un'arce del Palatino» (Carandini, ibid.).

12 Es tanto más notable y significativo el caso en que, por sumar montes a la orografía de Roma y alcanzar el legendario número de siete (Septimontium, Siete Colinas...), se incluyen en la lista accidentes topográficos que ni siquiera poseen la categoría de tales: «...Antistio Labeone elencava altrimenti i 'monti', ... come ci risulta de Festo, 458, 459, 476 (che è quanto dire Verrio Flacco) che così li nomina nel ordine: Palatinum, Velia, Fagutal, Subura, Cermalus, Caelius, Oppius (ovvero Oppius, Caelius), Cispius. (...) la Subura, che è notoriamente la valle tra Esquilino e Quirinale» (M. Pallotino, Origini e Storia Primitiva di Roma, Ed. Rusconi, Milano 1993: p. 71). 


\section{El río Rumon}

El testimonio mismo de Servio, que ha sido aducido como prueba de que la ciudad tuvo un nombre etrusco (Rumon= «río») viene a corroborar, por el contrario, si nos atenemos a las palabras del propio Servio, que Rumon es una palabra de origen itálico. Servio, considerando la propiedad del Tíber, a su paso por Roma, de erosionar y ocupar las tierras que están a sus dos riberas («stringentem ripas, radentem, inminuentem»), hace alusión a la etimología latina $-\mathrm{y}$, por ende, «itálica», no etrusca- de un (supuesto) antiguo nombre del río, del que no tenemos otro documento: «Nam hoc est Tiberini fluminis proprium, adeo ut ab antiquis Rumon dictus est, quasi ripas ruminans et exedens» (Serv. A. 8.63). La alusión a un verbo tan latino como ruminare, «rumiar»,(= ex-edere, «comer, roer») no deja dudas: Servio hace derivar Rumon de rûmis, «bolsa de los rumiantes» y a la vez «ubre», igual que los que de tal palabra derivan Rûma, «Roma», ya con el significado doble de «ubre»y «colina».

Por eso resulta lógico que A.Carandini, viendo cumplida la labor erosionadora del Tíber en el las antiguas lagunas del Velabro y de Trastevere, perfectamente simétricas a ambos lados del río, se sienta tentado a imaginarlas como dos mamas y a asociarlas con las «ubres» del comentario de Servio: «Las principales ensenadas del río vienen a representar como los dos senos del río, las dos rumae del Rumon». ${ }^{13}$ Lo más interesente en cuanto a la etimología de Rumon es que, lejos de ser una prueba del nombre etrusco de Roma, puede valer como un indicio de cómo en la primitiva fundación de la Urbe los nombres funcionaron en racimo: $Y$ así es notable ver que en los meandros enlagunados del Tíber (Rumon) encontramos la misma base etimológica (ruminare en Servio, rumae en Carandini) que en la diosa Rumina, en la higuera Ruminal y en la misma Roma < Ruma.

\section{B) Elementos gentilicios}

Inmediatamente después del nombre de la ciudad y de sus topónimos originarios vendría el de los hombres que estuvieron asociados a su fundación. Los historiadores griegos presuponían como axioma que el nombre de la ciudad se había formado a partir del nombre de su fundador (Rhome $>$ (Rhomolos) $>$ Roma). Pero aquí seguimos el camino inverso: Es el nombre de la ciudad el que nos conduce al de sus habitantes y entre ellos, como una primicia, el de su fundador.

\section{Romulus}

Si el nombre de Rómulo proviene de Roma, y no al revés, como la generalidad de los autores están de acuerdo en reconocer (cfr. Grandazzi, 1991, p.200), el problema de su etimología debe ser reconducido por los filólogos al problema del

${ }^{13}$ Carandini, Andrea. La nascita di Roma. Dèi, Lari, eroi e uomini all'alba di una civiltà. Einaudi, Torino, 1997, p. 115 n. 11; ver también Grandazzi , 1991, p.201. 
nombre de Roma. Excluida ya axiomáticamente la etimología a partir del griego Rhôme,»fuerza», la cuestión se pone entre el etrusco Rumon,»río», y el itálico Ruma,»ubre, colina».

Desde 1975 el etruscólogo Carlo de Simone ha tratado de establecer la etimología de Rómulo y de Roma en base al nombre etrusco del río Tíber..$^{14}$ Una inscripción encontrada en la necrópolis etrusca de Crocefisso del Tufo (Orvieto), grabada sobre el arquitrabe de la tumba 34 en epigrafía orvietana del s. VI a.C.,

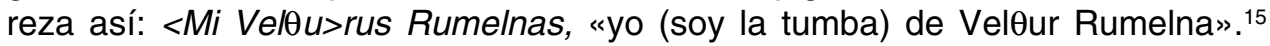
Esta inscripción ha permitido desde entonces a De Simone afirmar que «el prenombre que está en la base de Rumelna es seguramente *Rumele, forma etrusca que corresponde exactamente al latín Romulus" (de Simone, 2000 , p. 31 c.1). ${ }^{16}$ Establecida la equivalencia entre el etrusco * Rumele y el latín Romulus, el origen del nombre de Rómulo es remitido a la protohistoria de las lenguas etrusca y latina. En concreto, el etrusco posee — de forma paralela al latín — un tipo de nombres diminutivos e hipocorísticos a los que podría ser asimilado el nombre de Rómulo: «È agevolmente dimostrabile che in etrusco i nomi in -le rappresentano alcuni diminutivi, cfr. ad esempio Titele, diminutivo appunto di Tite (=Titus).» (ibid. p.31, c.2). ${ }^{17}$ En consecuencia, resulta legítimo postular un prenombre etrusco ${ }^{*}$ Rume (ver etrusco Tite), que estaría en la base de ${ }^{*}$ Rumele. $Y{ }^{*}$ Rume resultaría de la alternancia morfológica con ${ }^{*}$ Ruma (de cuya etimología nada se afirma, aunque deba suponerse un paralelo de rumon,»río»), siendo * Ruma idéntico al nombre de Roma. En el supuesto de que no existiera una etimología indoeuropea de esta raíz o base (como De Simone dice olvidando la alternancia del término latino rŭma / rūma, «ubre»), la etimología etrusca pasaría a poder ser razonablemente sostenida. ¿No es demasiada exigencia para tan poco bagaje como un aislado «Rumelnas"? Lo que De Simone no explica es cómo la serie de nombres etruscos * Ruma, ${ }^{*}$ Rumele, Rumelna, 'pasó a dar origen a una serie de nombres latinos. ¿No se trataría más bien de una mera casual homofonía entre dos series de nombres, ${ }^{*}$ Ruma, *Rumele, Rumelna (serie etrusca), y * Ruma, Romulus, Romilius (serie latina), que nada tendrían de común en su origen? $\mathrm{O}$, dicho de otra forma, ¿ha demostrado Carlo de Simone que el indocumentado *Rumele etrusco tenga algo que ver con el Romulus latino además de la mera coincidencia fónica de dos nombres que se asemejarían, pero que históricamente se ignoran?

En el año 1988 Carmine Ampolo replanteaba el estado de la cuestión ${ }^{18}$. A una serie latina constituida por Roma, Romulus, y Romilius (gentilicio de Rómulo), correponde una serie paralela en etrusco constituida por Ruma (ver Ruma en

${ }^{14}$ Cf. De Simone, Carlo. «ll nome del Tevere», en St.Etr. XLIII, pp.119-157.

15 Cf. De Simone, Carlo. «Le iscrizioni etrusche di Orvieto», Annali della Fondazione per il Museo Claudio Faina», IV, pp. 27-41.

16 De Simone, Carlo. «ll nome di Romolo», en Carandini 2000, pp. 31-32.

17 Andrea Carandini en diversos pasajes de su obra más reciente (cfr. Carandini, 2000) se ha sumado a esta interpretación de Rómulo como un nombre diminutivo.

18 Cfr. C.Ampolo, «Introduzione», en Plutarco. Le vite di Teseo e di Romolo. Fondazione Lorenzo Valla. A.Mondadori ed. 1988. A este respecto no estaría de más recordar al de Sanctis referirse a «l'ipote- 
CIE $5275=$ TLE 300), *Rumele, y Rumelna o Rumlna (ver «Studi Etruschi»XXXIV 1966, p. 108-9). Pero la conclusión de Ampolo es contundente. De estas series paralelas no es lícito concluir la prioridad de ninguna de las lenguas: «No es necesario pensar que Romulus y Roma deriven del etrusco" (Ampolo, 1988, p. XXXIII ). En cualquier caso, para Ampolo - sea cual sea el étimo de Roma- la tesis que propone que -ulus en Romulus es un sufijo étnico y no un diminutivo (o hipocorístico) sería la más probable: Rómulo no significa otra cosa que Romano, es decir, «el de Roma» (como Rutulus, Siculus, Aequiculus, Volsculus). ${ }^{19}$ De Simone cree poder destruir la equivalencia Romulus-Romanus: «El nombre propio Romulus es todavía hoy considerado como un étnico, alternativo a Romanus, por lo que vendría a significar 'el Romano' (Siculus-Sicanus). Pero el étnico Siculus no puede de ningún modo ser homologado" (Siculus<Sicilia)" (De Simone 2000: p.31, c.3). A eso se puede responder que no es cierto que Siculus proceda de Sicilia y no a la inversa (como de Romanus se formó Romania). El binomio Romulus/Romanus no cuenta con ningún topónimo del tipo Sicilia (como sería el nombre de la tribu Romilia). Lo mismo le pasa al binomio que surge de Tuscus, es decir, Tuscanus ${ }^{*}$ Tusculus (cfr. Tusculanum), que sin embargo posee Tuscania. Lo cual demuestra que ningún topónimo es obligado para probar la existencia del nombre étnico correspondiente: ver Rutulus, Aequiculus, Volsculus.

Grandazzi, 1991, p. 201, se adhiere a la tesis recogida por Carmine Ampolo acerca del nombre Rómulo («non si tratta di un diminutivo artificialmente costruito, ma di un nome veramente arcaico, del tipo Rutulus <...> o Volsculus <...»»); y añade el siguiente matiz: El nombre de Rómulo primero debía de pertenecer a toda la comunidad romana y en ese sentido era el gentilicio propio de los naturales de la primitiva *Ruma. Luego (igual que «Francesco» pasó de significar los «originarios del país de los francos» a denominar un/os individuo/s llamado/s «Francisco») en la Roma urbana el nombre de los naturales del país quedó fijado como «Romanos»; en tanto que Romulus «se convirtió en un nombre (o un cognomen)», en último término una «singularidad arcaica», al quedar reducida su aplicación a Rómulo, el fundador de la urbe..$^{20}$

También Tim J.Cornell (en Carandini, 2000, p. 47) se adhiere a la explicación étnica del nombre Rómulo: «Se trata de un simple eponimo formado en base al nombre de la ciudad. Son posibles otras explicaciones, pero, examinadas una tras otra, esta es la más probable» (y cita a Ampolo 1988, supra).

si (di Schulze!), che non è neppure neccesario combattere, delle due genti etrusche Ruma e Remne (p.219), che avrebbero dato origine a Roma e a'suoi due antichi fondatori» (De Sanctis 1907, p.207 n.2).

${ }_{19}$ Tal tesis fue ya asumida por Gaetano de Sanctis, 1907, p.207, quien por cierto se remite a un notable historiador coetáneo: «Ciò è dimostrato all'evidenza dallo SCHWEGLER, p. 420 seg.» Se refiere a Albert Schwegler, Romische Gheschichte, H. Laupp'sche Buchhandlungen, Tubingen 1867-72.

20 Ver ya De Sanctis 1907, p.207: «Romano è divenuto l'unico nome con cui si designavano i veri e reali cittadini di Roma, mentre Romolo si è ridotto a designare il cittadino mitico, il cittadino per eccelenza, l'eponimo". No obstante, hay que tener en cuenta un dato filológico muy instructivo: Romulus (que no hay que reducir a Romuleus, que sería mera metonimia) conserva el sentido de Romanus en el lenguaje poético. Así, Romula gens (HOR. Carm. 4.5; Saec. 47); Romula tellus (VERG. A. 6..877); Romula ficus (OV. Fast. 2.412); Romula hasta (PROP.. 5. 4.26). 


\begin{abstract}
La posición de A.Carandini en cuanto al étimo de Roma (y, por lo mismo, de Rómulo) es más compleja y puede parecer en ocasiones demasiado compleja. Por un lado, acepta $-\mathrm{y}$ a ella se remite con asiduidad - la existencia en el latín pre-urbano de una palabra ruma, "ubre, teta» (it. mammella) y alude en repetidas ocasiones al étimo latino rumis, «ubre», con el que ruma está intrínsecamente unida, y a la proximidad - hasta la confusión- de ambas palabras con -rūmen,-inis, de donde Rümina y Rüminalis (cfr. Ernout-Meillet, Dictionnaire Étimologique de la Langue Latine, s.v.). Por otro lado, sin embargo, renuncia a considerar ${ }^{*}$ Ruma una raíz latina y nos remite para su origen al etrusco, aunque —rozando la ambigüidad - considera la palabra a la vez "etrusca / latina" en virtud de una intercambiabilidad entre ambas lenguas, que es Ilamada competenza onomastica múltipla. ${ }^{21}$
\end{abstract}

En contra de la posición etrusquizante que representa De Simone se puede decir:

a) Los nombres gentilicios etruscos Rumele y Rumelna pueden también explicarse a partir del nombre latino * Ruma, y no exclusivamente como tirrenización de Romulo. Si, como el mismo De Simone afirma, el nombre etrusco * Rumele y el nombre latino Romulus son formas paralelas y equivalentes de Rómulo, ¿por qué deducir que la forma latina Romulus (que está documentada) es la trasposición de la forma etrusca ${ }^{*}$ Rumele (que no está documentada), y no a la inversa? La trasposición del latín al etrusco se hace tanto más probable por el hecho de que en itálico existe una raíz rŭm/rūm- (ver infra p. 146 a propósito de la higuera Ruminal), cuya vigencia en latín nos es perfectamente conocida; a diferencia de lo que pasa con $R u$ mon, el hipotético nombre del río Tíber que daría nombre a *Ruma, de cuya raíz etrusca y significado nada seguro se nos dice, a no ser lo que se puede saber en clave itálica e indoeuropea: "che il fiume sarebbe così chiamato in ragione o delle montagne da cui scende, o dei relievi che traversa, all'altezza, proprio del sito di 'Roma' ” (Grandazzi, 1991, p.201; ver supra p. 140).

b) Es quizá el nombre Roma el que hay que explicar como una helenizacion ideológicamente intencionada (Rhome:»fuerza») de Ruma. Sólo si esto último es verdad, se hace razonable la pretensión de la historiografía griega de ofrecer una etimología de Roma basada en un precedente autóctono ( ${ }^{\star}$ Ruma), que de esta manera a.- no hubiera sido una mera y total invención, que conduciría a una formulación inverosímil: «fuimos nosotros y no los autóctonos los que pusimos el nombre de Roma», y b.- hubiera sido más aceptable a los naturales de ${ }^{*}$ Ruma, que en consonancia con la historiografía griega del S. IV a.C. hubieran podido considerar un honor modi-

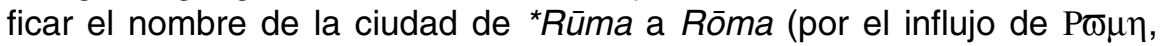
«fuerza»).

21 «Dall'appellativo etr. *ruma/ lat. ruma (per il quale l'etimo indoeuropeo non è stato trovato, per cui è probabile l'origine etrusca, e la tradizione romana dava il significato di mammella), derivano: 1) il palleonimo etr. *Ruma / lat. *Ruma > Roma e 2) il prenome etr. * Rumele / lat. *Romelos, Romulus» (Carandini, 1997, p. 289 n.35). 


\section{Romilia (gens)}

Según T.Livio (2.21.7) en el año 495 a.C. el territorio de Roma fue dividido en veintiún territorios (o «tribus», en la acepción etrusca del término): cuatro tribus urbanas -Palatina, Colina, Suburana y Esquilina-y diecisiete tribus rurales. De las diecisiete tribus rurales todas menos una (Crustumina) tienen un nombre terminado en -ia; y diez de ellas llevan el nombre de algún destacado clan de familias o «gente» patricia. Tal es el caso de la tribu Romilia. Lo sabemos porque uno de sus miembros (¡el único conocido!) Ilamado T.Romilio Roco Vaticano aparece en los Fastos como cónsul del año 455 a.C. y como uno de los decenviros del año 451 a.C.

Los filólogos actuales están de acuerdo en que el nombre de la gens Romilia procede de Rómulo. ${ }^{22}$ Sin embargo, ya en el año 1970 Emilio Peruzzi no creía que el nombre de la tribu Romilia representase una herencia onomástica a partir de la familia misma de Rómulo. Si Rómulo es, como hemos visto, un nombre étnico, y no un nombre de familia, el fundador de Roma - en caso de ser una persona real y no una creación legendaria con base en la realidad- llevaría en todo caso otro nombre gentilicio distinto. ${ }^{23}$

El anticuarista Festo afirma que el nombre de la tribu Romilia es anterior al de la gens, en el sentido de que la tribu Romilia recibió tal nombre por estar constituida por tierras pertenecientes a Rómulo (Paulo-Festo, p. $331 \mathrm{~L}$ ). El dato no merece crédito, pues «es indudable que los topónimos derivan del nombre de la tribu; y no al revés» (Tim J. Cornell, 1995<1999>, p.215). Pero al menos el nombre de la gens Romilia puede derivar del topónimo de Roma (<Ruma). En conclusión, podríamos decir que existió en Roma una «gens» llamada Romilia, la cual recibió su nombre de Roma a través de Rómulo; y del nombre de dicha «gens» tomó su nombre la tribu Romilia, cuyo territorio perteneció al clan de los Romilios quizá por haber sido adjudicado a Rómulo entre las tierras por él conquistadas. En cualquier caso, la forma Romilia, que en los testimonios epigraficos alterna con Romulia, ${ }^{24}$ debe entenderse como un gentilicio no de origen genético, sino de origen tribal.

\section{Ramnes (tribus)}

Cuestión más debatida es hasta qué punto el nombre de la tribu pre-etrusca de los Ramnes (nombre tenido comunmente por sinónimo de «Romanos») podría haber derivado de Rómulo. Varrón sigue siendo nuestra fuente principal acerca del

22 «...dal prenome latino Romulus è derivato infatti del tutto regolarmente (come Marcius < Marco) il gentilizio Romilius (per il rapporto formale cfr. Siculus: Sicilia) ... I'alternanza Sicilia-Siculus riflette la diversa colorazione di l.» (Carlo de Simone 2000: 31 y 32); "abbiamo quindi una serie costituita da: Roma - Romulus - Romilius» (C.Ampolo 1988: XXXIII).

23 «Se la gens Romilia, a torto o a ragione, avesse vantato una discendenza dal fondatore della città, ne avremmo senza dubbio qualche testimonianza...Ma di ciò non si ha traccia... anzi, Varrone ci attesta che...si chiamava tribus Romilia del toponimo Roma» (Peruzzi, 1970, p. 27).

${ }_{24}$ Ver por ejemplo Romul(ia) en CIL V.2785; y Rwmulia en IGRom. IV.262. 
origen y de la etimología de las tres tribus arcaicas de Roma: «El territorio romano estaba primero dividido en tres partes... Según Ennio los Titienses eran llamados así a partir del nombre de Tito Tacio, los Ramnenses a partir del nombre de Rómulo y, según Junio, los Luceres a partir del nombre Lucumón. Según Volnio, autor de tragedias etruscas, los tres nombres serían de origen etrusco» (VAR. L. 5.55).

Abundan las teorías contrarias a la relación etimológica entre Ramnes y Romulus:

4.a) «Ramnes, forse da interpretarsi in relazione al rhamnos, spina alba, ramno: inter genera arborum rhamnos appellatum a Graecis candidior et fructicosior (PLIN. Nat. 24.76)» (en Carandini «La Nascita...»: p.451 n. 20).

4.b) «poco attendibile la tesi de G.Radke (Archaiches Latein, Damstadt 1981, p. 41 sgg. (...) secondo cui da *rm-nna, 'la città di Remo”, sarebbero derivati il nome di Roma (Romna>Roma) e quello dei Ramnenses» (C.Ampolo 1988: XXXIII).

4.c) «Vanno tenuti distinti il nome di Remus (...), e il nome della tribu dei Ramnes (o Ramnenses), denominazioni che si inseriscono eventualmente in altre serie, rispettivamente latina ed etrusca ... (per l'etrusco Ramnuna ved. CIE 4939)» (C.Ampolo 1988: XXXIV).

4.d) «...» É inutile indagare se el vero nome di Romolo se celi in Ramnes» (Peruzzi, 1970, p. 30). Peruzzi, a propósito de la etimología de Ramnes, Tities y Luceres, se encomienda a Varrón («Ramnenses a Romulo..., sed omnia haec vocabula Tusca» (VAR. L. 5.55); pero se muestra excéptico con Varrón y con todos los antiguos, "che superavano la difficultà con un'impossibile etimologia oppure (come molti linguisti d'oggi) spiegando tutto con l'etrusco» (ibid. 26).

Pero, si como quieren los historiadores y arqueólogos actualmente, la institución de las tres tribus pre-etruscas, entre ellas los Ramnes, es tan antigua que debe sin duda adscribirse a la constitución romúlea de Roma, será lógico estudiar la relación etimológica — difícil- del nombre de los Ramnes con Roma.

\section{C) Elementos mitográficos}

Esta interpretación del nombre de Roma casa con toda la leyenda quasi-totémica que rodea el nacimiento de la ciudad y la figura de su fundador. Timeo de Taormina, el autor griego que enlaza la leyenda griega de Eneas con la tradición indígena latina, narra el episodio de la llegada de Eneas al Lacio y la fundación de la ciudad de Lavinium en el lugar donde se detuvo cansada la cerda que trajo el héroe de Troya, después de haber parido 30 lechones. Sus tetas, como las de la Loba Capitolina, son el elemento más característico de la estatua conservada en el museo de Lavinio. Evidentemente los elementos de esta leyenda no pasan de legendarios; pero pudiera ser que el elemento real fuera la predisposición a convertir en terreno de fundación (en medio de una geografía pantanosa) parajes con colinas fácilmente asimilables a las ubres de una cerda o de una loba. 


\section{La higuera Ruminal y la puerta Románula}

Que toda la saga mítica de Rómulo se halla vinculada a acontecimientos y a términos que se reclaman al nombre de Roma (<Ruma= «ubre»), es algo que parece muy claro a partir de un resumen del mito como éste que nos ofrece Andrea Carandini: «Secondo la saga romulea i gemelli vennero esposti e salvati al Lupercale, dove era anche la sacra ficus Ruminalis o di Rumina, dea del allattamento, dove era anche la lupa che offriva le sue rumae o mammelle ai gemelli salvati in riva al Tevere o Rumon, a sua volta rigonfio e straripato» (A.Carandini, 2000, p.114).

Todo la compleja serie de fenómenos toponímicos y gentilicios que previamente hemos expuesto lleva a pensar que la leyenda de la fundación de Roma se fraguó en base a la carga simbólica del nombre mismo de Roma. Ya hemos dejado asentado que el nombre de Roma precede al de Rómulo: éste sería solamente un patrónimico —Rómulo= «el Romano»- derivado de Roma. Es lógico ahora preguntarse si el nombre de Romulus (<Ruma) nació por influjo del relato mítico surgido en torno a la higuera Ruminal y a las ubres de la loba, como quiere A.Carandini ${ }^{25}$, o si, por el contrario, fue el nombre mismo de la ciudad (Ruma= «ubres») y el nombre patronímico de su fundador Romulus («el de Ruma« > «el de las ubres» > «el amamantado») lo que condujo hacia la idea mítica del amamantamiento por la loba. En principio, la idea misma de las ubres no implica necesariamente que se trate del milagroso amamantamiento de una pareja del gemelos humanos por una fiera. Nada es posible afirmar en el estadio actual de la investigación. Es probable que se tratara de un influjo recíproco, cuyo orden de prelación sea imposible por siempre determinar. Aquí nos limitaremos a poner en evidencia la mutua interrelación de todos estos factores toponímicos, gentilicios y mitológicos.

La higuera Ruminal fue probablemente un sitio cultual contemporáneo de la Roma naciente. Como su nombre indica, la higuera estaba dedicada a Rumina, una diosa asimilada a Fauna - la esposa de Fauno-, dotada con poderes generativos, a la que A.Carandini (1997, p.80) considera «relativa a una hipotética localidad *Ruma localizable a los pies del Palatino». Que el nombre de Rumina está basado etimológicamente en rūmen.-inis, «panza de los rumiantes», es indudable; pero rūmen- acabó en la conciencia de los hablantes latinos asimilado a rŭmis,»teta», como si ambas palabras procedieran de una única y comúm raíz *rŭm-/rūm- (cfr. Ernout-Meillet, Dictionnaire Étimologique de la Langue Latine, s.v.). De hecho, Rūmina se convirtió en una diosa característica del amamantamiento. Y la higuera Ruminal estaba dedicada a Rumina por el doble simbolismo del árbol, que se reclama a la fecundidad femenina, tanto por la forma de órgano

25 «Questi microtoponimi (ficus Ruminalis, porta Romanula...), che indicano forse in origine le falde orientali (sic) e meridionali del Palatino - le uniche rivolte verso il Rumon-e i cui nomi fanno capo ad uno stesso etimo, hanno dato poi il nome, forse ma non sicuramente (come si crede), al fondatore della città» (A.Carandini, 2000, p. 115). 
sexual de sus frutos (reproducción), como por la leche que destilan sus tallos (lactancia).

Rumina ejercía sus poderes no sólo en relación a las mujeres, sino también a todas las hembras bien dotadas de leche y ubres, como las de los ganados domésticos (cabras, etc.) y las salvajes (lobas...). La misma diosa Rumina alterna figura animal y humana; y -cuando sus dotes se traduzcan en relato mítico- en ambas representaciones tendrá capacidad para amamantar a los divinos gemelos Rómulo y Remo, sea como hembra animal (Fauna: Luperca, la legendaria «loba») o como mujer (Acca Laurentia, esposa del legendario pastor Fáustulo).

Todo ello nos conduce a hipotetizar al pie del monte Palatino, junto a la ensenada del Tíber que entra hacia el valle Murcia, un paraje al que los antiguos ya en fase pre-urbana pudieron dar el nombre itálico (pre-latino?) de Ruma (>Roma), por una coalescencia de motivos: a) la presencia a su alrededor de un conjunto de colinas, sobre todo la Palatina (cfr. Osco: ruma: «colina»); b) por la proximidad del río Tíber, al que sabemos que los antiguos llamaron Alba/Albula, pero que pudo en algún momento haber sido llamado Rumon por su propiedad de erosionar ambas laderas al pie del Palatino formando (ruminans, Serv. Aen. 8.63) dos ensenadas o mamas, una de las cuales entra por el Velabro hasta el pie de la cueva Lupercal; y c) «por la presencia en el paraje de la higuera Ruminal, ligada a la diosa Rumina, la diosa loba - cabra-, higuera hembra, nutricia por excelencia en cuanto diosa de la ruma o ubre" (Carandini 1997: 289). Teniendo en cuenta la peculiaridad del latín de denominar a las puertas por su capacidad de conducir a-fuera (fores), o sea, por el lugar hacia donde se sale, y no por el sitio a donde se entra, resulta lógico el nombre de las puertas que desde el Palatino pre-urbano conducían al paraje de la higuera Ruminal: la puerta Romana ( $<{ }^{\star} R u m a n a$ ?), que conducía directamente por las escaleras de Caco a la cueva Lupercal; y la puerta Romanula (< ${ }^{*}$ Rumanula? ), que podía conducir al mismo lugar a través del Velabro. Tanto la puerta Romana como la Romanula conducirían desde el enclave pre-urbano del Palatino a los pies de la diosa Rumina.

De las ubres de esta diosa había de nutrirse, como era natural, el fundador de la ciudad, que llevaría el nombre de Rómulo, «el de Roma», es decir, «el amamantado (por la diosa Rumina)". Igualmente había de pasar con su hermano Remo, cuando quedara conformado - por la razón que fuera- el mito de los gemelos. Es sugestivo el dato, transmitido por Tito Livio (1.4.5), de que «la higuera Ruminal... dicen que fue llamada Romular (Romularem vocatam ferunt)». ${ }^{26}$ La noticia testimonia que en la tradición primitiva, o bien Rómulo ostentaba en exclusiva el título de «el amamantado (por la diosa Rumina)», o bien que (si el epíteto «Romular» debe referirse a ambos gemelos) Ruminalis y Romularem son términos equivalentes; lo que invitaría a derivar el nombre de Romulus de la raíz ruma,»ubre», y haría remitir a ${ }^{*}$ Ruma el nombre de Roma, al que Romulus necesariamente está vinculado.

26 Ver también OVID. Fast. II,411 s.: «quaeque vocatur / Rumina nunc ficus, Romula ficus erat». 


\section{La cueva Lupercal}

¿Y cómo había de surgir el inevitable mito de la paternidad sobre los gemelos fundadores de Roma sino en relación con la misma Rumina, que es a la vez diosa del amamantamiento y de la fecundidad? La leyenda de Rómulo se incardina en esta mitología primitiva del Palatino. Y Roma deja de ser el único pueblo primitivo carente casi totalmente de una mitología propia. En ese contexto habían operado los historiadores que, negando a la primitiva Roma una historia propia (y habiéndola entregado a las manos de la historiografía griega y etrusca), privaron a Roma casi de cualquier resto de mitología primitiva propia y la obligaron a conformarse con la herencia - tardía - de la mitología culta griega (o, cuando más, etrusca).

Resultaba, por eso, indispensable reafirmar la existencia de mitos latinos y, en concreto romanos, en la época de la fundación de Roma (por un hipotético Rómulo, que se representa a sí mismo como individuo más que a un colectivo fundacional) y en el momento mismo de la imposición del nombre de Roma (<Ruma) a la nueva ciudad. Esta tesis ha sido abundantemente desarrollada por Carandini 2002, quien en su reivindición de la leyenda romúlea adopta el método comparativista inaugurado por Georges Frazer a principios del siglo Xx. Carandini se remonta a la documentación etnológica de los clásicos de la Antropología Cultural, sobre todo Lévy-Bruhl, y al testimonio concreto del filólogo italiano Angelo Brelich para el caso específico de una etno-mitología romana primitiva. ${ }^{27}$ En opinión de Carandini la existencia de una mitología romana primitiva (Rumina, Fauno, el dios Luperco, etc.) demuestra que la leyenda de los gemelos y de la loba está lejos de ser una creación tardía, como querría la escuela historiográfica más crítica y como repite gran parte de la filología etrusca, que se niega a retrotraer el terminus ante quem de la leyenda de Romulo y Remo más allá de los inicios del siglo IV a.C., fecha en que el conocimiento de la leyenda está ya de hecho documentado por el monumento público a la loba inaugurado por los hermanos Ogulnios (296 a.C.) y por monedas conmemorativas en las que aparecen ambos gemelos. ${ }^{28}$ Es cierto que, sin embargo, no faltan historiadores que acogiéndose a una lógica más amplia, como Arnaldo Momigliano y su escuela, no dudan de que, aun cuando la leyenda de Rómulo no es documentada por la historiografía romana hasta el siglo IV a.C., cuando los historiadores griegos la conectan con la leyenda troyana de Eneas -nacida en plena Roma de los Tarquinos-, sólo la preexistencia de una leyenda autóctona más antigua debió forzar a los griegos a reservar a Rómulo - y no a un griego - el honor de la fundación de Roma ${ }^{29}$.

27 Ver sobre todo Carandini, 2002, capitolo quinto, pp. 53-75.

28 Así en Massimo Pallotino, Origini e Storia Primitiva di Roma. Milano, ed. Rusconi, 1993, p.18, quien a renglón seguido es todavía más explícito y riguroso: «Parallelamente allo sviluppo della tradizione greca, anche se in generale piú tardivamente (lo dice esplicitamente Dionisio d'Alicarnasso), debe essersi formata una tradizione romana, ... cioè la leggenda dei gemelli e la fondazione della città da parte di Romolo» (ibid. p.20).

29 «Benché Romolo faccia la sua prima comparsa in questo testo greco (il siciliano Alkinos... intorno al 350 a.C. < F.Gr.H. 560 F.4 >, è difficile dubitare che la sua connessione con Enea fosse artificiale e im- 
Así, pues, en vez de considerar la leyenda de Rómulo producto de una invención artificiosa de los historiadores griegos de los siglos v-IV a.C. -que extrañamente habrían proyectado a la época de la fundación de Roma un tipo de pensar impropio de ellos y que, por tanto, difícilmente podrían haber inventado-, es más razonable tener en cuenta que justamente la mitología primitivista que acompaña toda la leyenda de la Roma naciente es propia del estadio primitivo en que se hallaba la Roma del s. vIII a.C., como demuestra la comparación con los hallazgos de la etnografía contemporánea que se ocupa de los pueblos que actualmente viven en estadio primitivo. ${ }^{30}$ Por ello, resulta coherente tomar como auténtica la leyenda fundacional de Roma por Rómulo y tenerla por originada en el tiempo en que cronológicamente se sitúan los acontecimientos narrados en su versión tradicional y canónica. ${ }^{31}$

Es precisamente en la estela dejada por esa leyenda autóctona romana, donde se trata de encontrar algún indicio final de la conexión del nombre de Roma (<Ruma) con los gemelos Rómulo y Remo amamantados por la mítica loba en la cueva llamada Lupercal. Resulta evidente en sí mismo que la existencia de una leyenda fundacional centrada en el milagroso amamantamiento de los futuros fundadores de Roma avala la tesis de Roma < Ruma, en este caso «la ciudad de las ubres», más que la "ciudad de las colinas», aunque ambas acepciones resultarían equivalentes y equiparables.

Y precisamente en las raíces de esa leyenda romúlea la etnografía actual encuentra indicios suficientes para reconstruir un estadio primitivo de la cultura oral romana, un estadio en el que el totemismo habría prestado a los fundadores de la ciudad elementos míticos adecuados al relato fundacional. El culto del dios lobo (Luperco) y toda la leyenda de la loba que amamanta a Romulo se insertan bien en un marco quasi-totémico: El lobo podría haber sido el animal totem del clan fundador de Roma, como el pájaro Pico podría haber sido el totem de un clan de Lavinio y la cerda blanca (que a Eneas engendra treinta cerditos) el de Alba Longa. No es que así vayamos a dar por seguro un cierto totemismo romano, ${ }^{32}$ pero nos bastará constatar que tiene visos de verosimilitud. Esa era la opinión de un grande de la antropología, como Marcel Mauss, a quien en su primera obra le parecía posible que los pueblos mediterráneos hubieran conocido una forma peculiar de totemismo, pero improbable que entre ellos hubieran estado los romanos. Más tarde cambió de opinión sobre este tema: el dios lobo (Luperco, Marte ..., loba madre,

posta dall'essistenza di una leggenda indigena romana, che i greci dovevano tenere in conto» (Arnoldo Momigliano, Roma Antica. Firenze, Sansoni editore, 1989, p. 9).

30 Ver toda la discusión sobre este asunto en A.Carandini, 2002, cap. 1-8, y passim.

31 Como dice A.Carandini (loc.cit. pp. 91 y 225), parafraseando próxima y remotamente a E.Cassirer y a Schelling respectivamente, «sembra impossibile che a un popolo già essistente venga ad aggiungersi una mitologia». Por el contrario, tal mitología -que, cuando se separa del ritual y se da en forma narrativa tiende a encarnarse en la historia, como la leyenda de Rómulo- es un presupuesto de la fundación de ese pueblo, a la que es connatural y contemporánea.

32 "Non è questione di presupporre a tutti i costi un totemismo originario dei Latini» (Carandini, 2002, p.123). 
etc. y sobre todo un clan que lleva su nombre (los Lupercos?) le parecieron pruebas fehacientes de totemismo. ${ }^{33}$

Gaetano de Sanctis fue el primero, que yo sepa, entre los filólogos e historiadores de Roma, que - sin desarrollar ampliamente el tema - sugirió esta interpretación totémica de la leyenda fundacional de Roma. ${ }^{34}$ Y Alexandre Grandazzi, asociando el dato al nombre mismo de Roma (<Ruma), observó que los romanos no eran los únicos entre los pueblos itálicos que llevaban ya en su nombre la impronta de una animal totem, el lobo: más al Sur, en el interior de la península itálica, se encuentra el pueblo de los Irpini, cuyo nombre significa «los del lobo», pues en la lengua osca lobo se decía hirpus. Lo cual indicaría que para los hirpinos, como para los primitivos romanos, el lobo había sido el animal totem. ${ }^{35}$ Andrea Carandini enlaza perfectamente con esta corriente y, aunque, como hemos visto más arriba, él - consciente de la despiada crítica de Lévi-Strauss al totemismo- ${ }^{36}$ marca su distancia hacia una adopción demasiado precipitada de la teoría totémica, aplica fielmente la terminología totémica en su interpretación realista de la primitiva leyenda romana. Más allá de las debilidades internas que puedan lastrar la teoría totémica misma, en el caso de un hipotético totemismo romano (o griego) es aún más decisiva - como el mismo Carandini, 2002, passim, pone en evidencia- la resistencia de helenistas y latinistas a reconocer vigor a otro método de investigación en su materia que no sea la filología clásica quoad talis. Pero, al menos en cuanto a la Roma primitiva, ¿no es evidente que el método histórico nos obliga a situarnos en un período del relato fundacional (s.VIII a.C.) en que lo único con que se puede contar es con una tradición oral dispersa aquí y allá en la documentación posterior y, no existiendo literatura escrita contemporánea a los hechos, el recurso a la filología es insuficiente y sólo la adopción de un moderado comparativismo etnológico puede ser lo adecuado?

¿Qué es sustancial al totemismo y qué de ello podemos encontrar en la tradición literaria latina? Una fórmula célebre decía que el totemismo es el culto de un antepasado en forma animal o vegetal (fetichismo), más el tabú de casarse con personas del propio grupo étnico por encima de la familia (exogamia), más una forma de clasificación étnica por herencia materna (filiación matrilineal). Así definía el totemismo en la segunda mitad del siglo XIX el escocés Mc Lennan, a quien se considera el inventor del mismo. ${ }^{37}$ Lévi-Strauss en su libro sobre el estado actual del totemismo niega la existencia real del mismo, calificándolo de una pura ilusión, la «ilusión totémica», y pretende disolver todo el fenómeno del totemismo en un mero sistema pre-racional — pero en el fondo «razonable»— de clasificación clá-

33 M. Mauss, Manuale di etnografia (1939), Jaca Books, Milano 1969; cfr. A.Carandini, 2002, p. 124.

34 Ver Gaetano de Sanctis, Storia dei Romani, vol. I, Fratelli Bocca edit., Torino 1907, p.113 s.

35 «...Il lupo, come per i primi Romani, era stato l'animale totem» (Grandazzi, 1991<1993>, p. 200).

36 Ver sobre todo Claude Lévi-Strauss, 1962: Le Totémisme aujourd'hui, Paris, P.U.F.; y La pensée sauvage, Paris, Livrairie Plon (trad. castell.: Fondo de Cultura Económica, Buenos Aires 1964; trad.ital. II Saggiatore 1964, y EST 1996).

37 Todo este asunto puede ser estudiado en Claude Lévi-Strauss, 1962<1980>, sobre todo pp. 5-23. 
nica, o gentilicia. Aunque en la afirmación —-tendenciosa- de C. Lévi-Strauss «el pretendido totemismo escapa a todo esfuerzo de definición absoluta» (de définition dans l'absolu), ${ }^{38}$ al menos en una cierta área de pueblos primitivos, en América y en Oceanía, el area de las sociedades frías (frente al área de las sociedades calientes, o sea, los pueblos del área semita e indoeuropea), allí la cultura totémica parece sólidamente atestiguada. Andrea Carandini recomienda tener en cuenta que el «ilustrado» intento de Lévi-Strauss, para eliminar las formas pre-racionales de pensamiento (emocional, religioso), despoja al totemismo de su aspectos más salvajes y lo reduce a un puro sistema de clasificación social, en lo que no hay que ver más que una consecuencia del método estructural del antropólogo francés, quien no comtempla en el pensar más que un sistema — racional- de establecer y mediar oposiciones.

Demos por asentado que es imposible hacer entrar a toda forma de totemismo en una sola categoría. Bajo el nombre de totemismo podemos englobar toda una amalgama de fenómenos heterogéneos, pero en los que se dan siempre al menos los componentes siguientes: 1) Preexistencia de un antepasado común -animal o vegetal-, del que procede todo un grupo social (por ejemplo, el laurel, al pájaro pico, el lobo). 2) Pertenencia al clan (o conjunto de familias emparentadas) de ese antepasado común (lobo). 3) Prohibición tabú de eliminar o matar y comer a ese antepasado común (el lobo). 4) Ritual de solidaridad entre todo el grupo, por medio del sacrificio de ese antepasado común (el lobo), única restricción al tabú de su asesinato, al que además en algunos casos se devora como forma que tiene el grupo o cuerpo social de apropiarse del cuerpo y de las habilidades del antepasado común. 5) Tabú de matrimonio dentro del propio clan. Y a la vez sistema de herencia del nombre y de la sangre del antepasado a trevés de la madre.

Aunque es arriesgado, como consta, querer encontrar signos evidentes de totemismo en cualquier cultura, y más arriesgado aún quererlos encontrar en una de las conocidas como sociedades calientes, la latina, no obstante podemos rastrear en Roma una mitología y una leyenda con características que podríamos prudentemente llamar «quasi-totémicas»:

a) El dios Luperco o Marte, padre de Rómulo.- Sobre una mítica hierogamia del dios Luperco, lobo, asimilado a Marte, con la diosa Rumina o con la princesa latina Rhea Silvia respectivamente, hemos hablado ya bastante en los epígrafes anteriores, hasta el punto de poder dar por suficientemente claro y zanjado este punto.

b) Los clasificados como hijos del lobo.- Marcel Mauss sabía que el totemismo debe funcionar como un sistema de clasificación. Sin eso, un pretendido totemismo no pasaría de un mero culto teriomorfo, Por eso, Mauss trató de encontrar en Roma algún grupo social que pudiera identificarse con el clan

38 Claude Lévi-Strauss, Le totémisme aujourd 'hui, P.U.F., Paris 1962<1980>, p.11. 
del lobo. De no encontrase tal grupo social, el culto de la cueva Lupercal y las fiestas Lupercalia no pasarían de ser una cierta forma de zoolatría. En la información que A.Carandini (loc.cit.) suministra sobre el particular, parece ser que el ilustre antropólogo vio en los Lupercos (?) el grupo que pudiera remontarse a Rómulo como a su antepasado. ${ }^{39}$ La suposición de M.Mauss está mejor fundamentada teniendo en cuenta que los Lupercos, aunque son en sí una mera fraternidad religiosa, y no un clan, no son una fraternidad que carezca de una base clánica: Eso los acreditaría como sistema de clasificación, ya que los Lupercos se dividían en un subgrupo perteneciente al clan de los Fabios y otro subgrupo perteneciente al clan de los Quinctios. ${ }^{40}$ Así lo documenta Mastrocinque, quien de paso (loc.cit.) nos recomienda no olvidar que las Lupercales eran una fiesta primordial, en cuanto al contenido «primitivo» de la ceremonia en sí, anterior al siglo vIII a.C., es decir, más antigua que el propio Rómulo. «Más antigua que el propio Rómulo" quiere decir que el fondo totémico de la fiesta se remontaba a la cultura prehistórica (¿neolítica?) y preliteraria de Roma; lo que no impide que precisamente a ese fondo cultural se sobrepusiera la figura de Rómulo, primero como antepasado primordial, y luego, con el nombre de Quirino, como el dios totémico de Roma (a la par de Marte, el dios Luperco y lobo padre). Mastrocinque, evitando mencionar siquiera la palabra totemismo, se comporta con la misma discreción que Angelo Brelich, a cuyos estudios se confía. Para Angelo Brelich, el verdadero padre y totem de los romanos habría sido esa divinidad animalesca que la tradición romana llama Fauno -fundido primero con la figura arcádica de Evandro y luego con el dios Marte ${ }^{41}$ - : «La saga de Fauno y de la transición desde la animalidad salvaje a la cultura eran celebradas en fiesta de las Lupercalia, in las que se insertó la presencia de Rómulo y Remo, considerados los primeros Luperci. La carrera ritual de febrero alrededor del Palatino representaba ritualmente la irrupción de los antepasados semiferinos, que con sus látigos fecundaban milagrosamente a las mujeres romanas, como Fauno había fecundado a Fauna, Hércules a la Bona Dea y Marte a Rhea Silvia» (Mastrocinque, 2000 , p. 52). Así pues, podríamos considerar a los Lupercos como los componentes del clan del lobo. Si Rómulo y Remo fueron a la pary en estructura gemelar, los dos primeros Lupercos, se entiende que tras ellos la líneas de clasificiación se dividiese en dos (como podría testimoniar, hipotéticamente, la posterior subdivisión de la fraternidad lupercal en Lupercos

39 «Varrone (n.16) sosteneva (en S.August. Civ.D. XVIII, 17) che in origine i Luperci si trasformavano in lupi» (Attilio Mastrocinque, «Romolo alla luce delle nuove scoperte», en Carandini A.-Cappelli,R., edit., 2000, p. 53).

40 «La festa dei Lupercalia aveva, per l'appunto, una dimensione squisitamente gentilizia, poiché i Luperci erano divisi in due confraternità afferenti a due gentes, i Luperci Fabiani e i Luperci Quinctiales, legati ai Fabii e ai Quinctii» (Mastrocinque, 2000, p. 53).

41 «lerogamia fra Fauno, identificato con Marte, e Fauna (Rumina)» (A.Carandini 1997, p. 217). En efecto, el Lupercal, donde los gemelos habían sido nutridos por el pájaro pico y por la loba, era una cueva sagrada consagrada a Marte (Verg. Aen. 8.630) 
Fabiani y Quinctiales). En cualquier caso la muerte de Remo en el contest por la fundación de Roma pasaría a significar que en la fase urbana de Roma el clan de los Lupercos estaría ya únicamente representado por los descendientes de Rómulo.

Y aquí es donde cobra importancia la tribu de los Ramnes o Ramnetes. Cuando Varrón testimonia que las tres tribus primitivas de Roma, Tities, Ramnes y Luceres, tenían nombres etruscos (dato que por cierto atribuye sospechosamente a un etrusco, el escritor de tragedias Volnio, ${ }^{42}$ nada afirma sobre el origen de la institución misma. El contexto en que nos estamos moviendo nos lleva de forma natural a hacerlas remontar a la primitiva Roma en el acto mismo fundacional. Carandini afirma que la división en tres tribus, treinta curias y tres mil soldados, constituye el núcleo organizativo principal en la fundación de Roma y que nadie ha logrado demostrar que es de edad reciente, siendo así que el dato, como cualquier otro de carácter antropólógico, invita a retrotraerlo a la época primitiva de la ciudad (A.Carandini, 2000, p. 95). Por su parte, ya hace más de treinta años el filólogo Robert Palmer dejaba fuera de toda duda que Ramnes es un nombre que tiene que ver sin duda con un sistema de clasificación, aunque el origen del nombre de las tribus no es seguro (ver Tito Livio, I, 13, 10-11) ${ }^{43}$. Si, como aquí creemos, Ramnenses deriva de *Ruma, «(la ciudad de las) ubres», la adopción de una cultura totémica en Roma haría coherente el que la tribu de los descendientes del fundador se autodenominaran «los que (por ser hijos del lobo) maman de la loba». A la pregunta de por qué hemos pasado del clan a la tribu como forma de clasificación totémica parece ofrecerse una respuesta obvia: En el sistema tribal el clan es la unidad natural de clasificación totémica y el tótem encuentra en el primitivo sistema tribal su estado propio. Pero al pasar de una sociedad tribal a una sociedad urbana, como fue el caso de Roma, el totemismo ya no es sistema cultural propio y solo se conserva como una forma de reminiscencia religiosa y como sistema de clasificación secundario. Y en un núcleo de población ampliado a diferentes naciones y razas, como es la ciudad de Roma, el único criterio de clasificación étnica viable ya no es el clan —que haría inacabable la clasificación-, sino una forma más compleja y compuesta como es la tribu, que consta de curias, las cuales no son ya clanes individuados sino en muchos casos asociaciones de clanes («la organización en tribus y curias, consustancial a la fundación», <cf. A.Carandini 2002, p.107>). En todo caso, un sistema de clasificación resulta proporcional al nivel orgánico del cuerpo social: Como la tribu se organiza en clanes, así la ciudad Estado, nivel superior a la tribu- se organiza en tribus. El siguiente nivel de sociedad,

42 Varro Lingua Latina, 5,55.

43 "Yet Ramnenses and Ramnetes are ethnia» (E.A. Robert Palmer, The archaic community of the Romans. Cambrige University Press, 1970, p.7 ). «The origin of the names cannot be ascertained « (ibid. p. 8). 
el Estado, se organiza en ciudades (cada una con su respectivo territorio jurisdiccional o «región»).

c) Sacrificio y banquete Lupercal.- Ninguna reminiscencia de prohibición totémica de matar lobos como tabú de respeto al antepasado de los Lupercos. Quizás esa prohibición existió durante la época hipotética en que los Lupercos fueron no una mera fraternidad religiosa, sino un verdadero clan de hijos del dios Lobo. En todo caso, tal prohibición es uno de los puntos menos omnipresentes en ese fenómeno heterogéneo que es el totemismo; por eso, su ausencia en Roma no constituye una objeción de peso decisivo contra el totemismo que aquí hipotetizamos.

Pero hay indicios seguros de un sacrificio ritual del dios Lobo: «...durante las Lupercalia se sacrificaban también perros» (Mastrocinque, 2002, p.53: Plu. Quaest.Rom. 68 y 111; Rom. 21) ${ }^{44}$.

Y queda además el tema de Rómulo convertido en víctima sacrifical (el luperco Rómulo, el hijo del Lobo, adopta la naturaleza ferina de su dios padre Fauno; ver la noticia de San Agustín <supra>, según el cual los Lupercos se transformaban en lobos), que es despedazado por los senadores de Roma en el momento de su muerte, o ascención a los cielos (LIV. 1. 16,4), un leit-motiv en la visión carandiniana de la leyenda fundacional (ver Carandini, 2002, p. 100 y passim), quien asimilando así a Rómulo y Osiris conduce a una cierta plenitud el contenido quasi-totémico del mito romúleo: «Una vez asesinado, Rómulo, el hijo de Marte, es asimilado a Quirino» (Carandini, 2002, p. 118). Y entonces es eucarísticamente consumido en forma de grano de farro (ver Carandini, 2002, loc.cit. y. passim). ${ }^{45}$

d) Rapto de las Sabinas y exogamia romana.- Es justo a este nivel de la tribu, en el que tenemos testimonio de una primera forma histórica de clasificación social asociada al tabú del incesto. El episodio mítico-legendario del rapto de las Sabinas está a la base de este sistema de clasificación matrimonial. Tito Livio (I, 9-13), que en otros puntos de la primitiva historia de Roma era poco amigo de aceptar fácilmente las leyendas, acoge como verídico el relato del rapto de las Sabinas. Sin embargo, ningún historiador actual admite al pie de la letra el rapto. Historiadores y antropólogos contemporáneos dicen que, por medio de la leyenda de las Sabinas raptadas, los romanos querían explicar alguna constante de su civilización y de su sociedad. Se han dado muchas interpretaciones sobre el sentido profundo de este episodio. Las más conocidas y actuales son las siguientes: a.- La población romana estaba compuesta desde los tiempos más antiguos de diferentes grupos étnicos: primeramente existieron allí latinos procedentes de

44 cf. M.Corsano, «Sodalitas et gentilité dans l'ensemble lupecal», en RHR, 191.2, 1977, pp. 137-158.

45 Por mi parte, me hago el propósito de retomar este tema que, aplicado a Dionso despedazado (y devorado) por los Titanes, ya desarrollé en mi tesis doctoral (ver Angel Luis Casquillo Fumanal, «Naturaleza titánica». Poder y disidencia en la Mitología Clásica. Universidad Autónoma, Madrid 1991). 
Alba Longa y Sabinos; después se añadieron los etruscos. «Los romanos se coaligan con los sabinos para hacer de Roma una ciudad reforzada por la unión de dos pueblos y de dos reinos en una sola entidad, geminata urbs (Grandazzi, 1991, p.228). b.- El rapto de las Sabinas explicaría la repartición del poder - rara en la antigüedad- entre Rómulo y el sabino Tito Tacio. Esta dualidad era un paralelo de la frágil y mítica dualidad anterior entre Rómulo y Remo (Mommsen), y una anticipación de la sólida costumbre romana de dividir el poder entre los dos cónsules (Wiseman, 1999; ver De Sanctis 1907, p.221). c.- En la Roma primitiva, como en otras partes, el marido adquiría a la mujer comprándola contra su voluntad. El rapto de las Sabinas era quizá la justificación de los ritos nupciales romanos: En la boda romana el novio arrebataba a la novia de los brazos de su madre y después la introducía en volandas en su propia casa. d.- Como en las tribus primitivas actuales, en la antigua Italia había distintos regímenes matrimoniales: Algunos pueblos paracticaban la «endogamia»: obligación de casarse entre los miembros del propio clan. Otros pueblos empezaron a practicar la «exogamia»: derecho a casarse con personas ajenas al clan y prohibición-tabú de casarse con miembros de la propia familia. El «Rapto de las Sabinas» podría ser la explicación en lenguaje mítico de las causas por las que se inauguró en Roma el régimen matrimonial exogámico: «De otra forma, los latinos no hubieran podido casarse más que con latinos, los etruscos con etruscos, y los sabinos solamente con sabinos" (Palmer, 1970, p. 197). ${ }^{46}$

Es posible que en todos estos puntos haya una parte de verdad. Pero es probable que el punto central de toda la interpretación sea el inicio de la exogamia en Roma, de la que los ritos nupciales serían el símbolo ritual y la dualidad étnica y política de Roma sería una mera consecuencia.

Tradicionalmente la exogamia aparece como un aspecto del «totemismo". Es más, no hay totemismo sin restricciones matrimoniales por encima de la mera familia: En las tribus primitivas se desarrolla un tabú que prohibe casarse no sólo con miembros de la propia familia en primer grado, sino también con los miembros del propio clan, que están bajo la protección de un mismo tótem animal. En tales casos se documentan ejemplos de raptos de mujeres de otros clanes. Por otra parte, el sistema de clasificación totémica va unido, como hemos dicho más arriba, a la filiación matrilineal, lo que al menos podría explicar por qué, tras el rapto y la victoria de Rómulo en la guerra entre latinos y sabinos, las curias de Roma recibieron el nombre de las mujeres sabinas raptadas (LIV. 1. 13. 6-7). ${ }^{47}$ Pues bien, en la

\footnotetext{
46 Ver, sin embargo, Kostler, «Raub und Kaufehe bei den Römern», en Z.S.S., 1943, según el cual los romanos no conocieron nunca el matrimonio por rapto o por compra.

47 R.Palmer (1970) no ofrece ninguna explicación de por qué las curias recibieron este punto de partida de clasificación matrilineal. En ausencia, la explicación aquí aportada resulta razonable y coherente con la globalidad de hechos antropológicos aquí mencionados. La filiación matrilineal podría aclarar otro
} 
Roma romúlea el tótem debió de ser el dios-lobo Marte, o Luperco; en Alba Longa, la cerda blanca; en Lanuvio, el pájaro-pico (que Carandini ha trasladado también a la cueva Lupercal). Como es propio de un sistema totémico, el Marte-lobo ostenta la paternidad sobre todos los romanos y sólo puede ser sacrificado en sus fiestas, las Lupercalia (mes de Febrero), en las que purificaba a toda la ciudad y hacía fecundas a las mujeres. Primero la fraternidad de los Luperci y luego toda la tribu de los Ramnes representaban en Roma la descendencia de Rómulo. El Rapto de las Sabinas mitifica el episodio histórico por el que se inauguró la exogamia entre latinos y sabinos. Un problema quedaría por resolver: ¿Existió un tabú del incesto dentro de las tribus de Roma? Al menos en etapa histórica sabemos que el tabú quedó restringido - como en la generalidad de las sociedad urbanas-a la sola familia de primer grado.

En todo caso, las líneas generales del «rapto de las Sabinas» demuestran que el relato se remonta a mecanismos del imaginario colectivo presentes en todas las civilizaciones primitivas ${ }^{48}$ Estamos, pues, si no ante un dato histórico, sí ante un hecho antropológico, que unido a la suficiente documentción arqueológica podría ser sustancial para confirmar el quasi-totemismo romano. Y, como ya hemos indicado — siguiendo a Carandini-, tal marco totémico de la primitiva leyenda romana confirma la posibilidad de hacer remontar al siglo VIII a.C. la gestación oral de la leyenda fundacional de Roma. Y a la gestación actual de la leyenda seguiría, sin duda, la realidad misma de la fundación, fueran o no históricos de nomine los personajes a que la leyenda se refiere. Naturalmente nadie quiere probar que es histórico que un dios Lobo o dios Marte, existente, fecundó a una princesa latina, ni

de los puntos oscuros de la primitiva leyenda romana: la sucesión de Rhea Silvia. El relato tradicional planteaba un problema: El rey usurpador Amulio decide consagrar como vestal a su sobrina Rhea Silvia, hija del rey destronado, Numítor, para evitar que resultara embarazada. Pero los temores de Amulio a una posible descendencia masculina de Rhea Silvia son incompatibles con los usos hereditarios de Roma en época histórica. «En el caso de que Rhea Silvia se casara y tuviera un hijo varón, ¿en qué podría el niño obstaculizar los planes de Amulio reclamando para sí la sucesión de Numítor, dado que un nieto no podía nunca ser el heredero de su abuelo materno? Para entender la conducta de Amulio, habría que tomar en consideración un sistema de sucesión regia en que el poder fuera transmitido por las mujeres...» (Michel J.H., Mariage romain et ethnologie française, 1979, p. 109; citado en J.Poucet: 1985, p. 112). Es evidente que la consideración de un posible totemismo romano cambia la situación: en un sistema de filiación matrilineal era justamente un hijo de Rhea Silvia quien hubiera heredado el nombre de (la esposa de) Numítor y el consiguiente derecho al trono de Roma. ¿No es el nombre mismo de Silvia un nombre matrilineal? Un indicio de ello parecer ser la propia lista de reyes de Alba suministrada por Tito Livio (LIV. 1. 3. 6-9): El hijo de Ascanio se llama Silvio (¿de una hipotética madre Silvia, en vez de «casu quodam in silvis natus»? Todos sus sucesores se llaman Silvios, ¿por el padre o por la madre? El hijo de un tal Agrippa, por ejemplo se llama Romulus Silvius: ¿No es este, entonces, el nombre que corresponde al mismo fundador de Roma, nieto de Numítor, en cuanto hijo de Rhea Silvia?

48 Los casos de matrimonio por rapto documentados por los etnógrafos en algunas sociedades tribales, ¿pueden servir para confirmar la historicidad del legendario Rapto de las Sabinas o la existencia de un matrimonio «por rapto» en la más antigua comunidad romana? Seguramente no: «La comparación etnográfica ... demuestra simplemente que la tradición romana nos presenta hechos que no son aberraciones etnológicamente hablando... Pero, ¿cómo estar seguros de que también Roma ha conocidos esos casos y esas reglas? La etnografía sola no puede confirmar la historicidad del relato romano acerca de las Sabinas» (J.Poucet, Les origines de Rome, 1985, p.112). 
que una loba salvaje fue capaz de alimentar de sus ubres a dos niños gemelos. No es imprescindible que la ciudad de Roma fuera fundada en forma milagrosa, ni que el autentico fundador se llamara patronímicamente Rómulo: «Y si el núcleo de la leyenda no refleja la verdad histórica del soberano fundador o la refleja de manera mistificada, ciertamente es el espejo de las aspiraciones del ambiente regio y de la aristocracia de la primitiva Roma, que es lo que interesa más desde el punto de vista histórico" (Carandini, 2002, p.228). Para nuestro propósito, basta que el nombre de la ciudad haya surgido en ese ambiente en el que la presencia de un culto primordial a la diosa Rumina, una presencia mítica de la figura del dios Luperco, una hierogamia sagrada, y diferentes aspectos quasi-totémicos de la primitiva cultura romana, hacen verosímil - y aun muy probable — la identificación de los fundadores de Roma con hijos del lobo, es decir, miembros del clan de los que se alimentan de las ubres de la loba: En tal ambiente el nombre más apropiado para la ciudad era *Ruma, "la ciudad de las ubres», sobre todo teniendo en cuenta la orografía del terreno, "ciudad de las colinas», y las ensenadas, hinchadas como mamas del río Tíber, «ciudad del río que se derrama». Y no era de extrañar que en tal contexto onomástico, el fundador de la ciudad, fuera quien fuera - una persona individual o un grupo- fuera personificado en la leyenda con el nombre de Rómulo (< ${ }^{\star}$ Rumolo), «el que mama de las ubres»). La coherencia de todo este conjunto mítico-histórico-geográfico-filológico nos parece, cuanto menos, digna de tenerse en cuenta.

Todo el complejo entramado toponímico-gentilicio-legendario se sostiene coherentemente sobre el fundamento del nombre de ${ }^{\star} R u m a$, con independencia de la mayor o menor entidad histórica del fundador de la Urbe. En conclusión:

\section{a) La teoría Ruma tiene éxito donde ya lo tenían las teorías precedentes.}

Ofrece una etimología de Roma ( $<{ }^{*}$ Ruma), con las mismas garantías de autenticidad gramatical que Rhome o Rhumon. Es más, Ruma añade la ventaja de tratarse de una palabra autóctona -itálica (indoeuropea)—, frente al griego Rhome y al etrusco Rumon: Una palabra de etimología autóctona para Roma es coherente, y aun necesaria, a la leyenda fundacional, que a partir de los nuevos descubrimientos arqueológicos se nutre de elementos esencialmente indígenas.

b) La teoría Ruma tiene éxito donde las teorías precedentes (Rhôme y $R u$ mon) fallaban:

Ruma constituye un nombre con carácter explicativo fuerte («ciudad de las ubres, ciudad de las colinas»), frente a la supuesta etimología etrusca Rumon, «río», que ofrece sólo un débil poder definitorio y que parece incapaz de delimitar una ciudad dentro de un espacio tan vasto como el río Tíber. Además, Ruma es un nombre coherente con la nueva historiografía que rodea el relato fundacional de la ciudad, plagado de ubres y de colinas, mientras que la vieja teoría del nombre de Rhome se inscribe en un marco que hechos históricos complementan y clarifican (ver infra). 
Tanto la teoría griega (Rhome) como la teoría etrusca (Rumon) nacen de un intento de conquistar para la civilización griega o etrusca el mérito de la Roma naciente. Pasada ya la fiebre etrusquizante, la interpretación latina - a fortiori itálica e indoeuropea-, vindica para sí en justicia el derecho de devolver a la cultura romana primitiva autóctona la elección del nombre de su propia ciudad en un contexto antropológico propio. Día a día los hechos arqueológicos van dando a esta escuela su merecida razón.

c) La etimología *Ruma se inserta en un conjunto más amplio de hechos explicativos y es capaz de englobar dentro de sí a las dos teorías rivales. La teoría Roma $<^{*}$ Ruma es internamente coherente y a la vez demuestra su poder catalizador haciéndose externamente receptiva hacia las otras teorías, a las que encaja en su estructura como piezas complementarias, pero fundamentales, de un sistema acabado en sí mismo.

Así, el binomio Roma $<^{\star} R u m a$ toma sus raíces en la leyenda misma fundacional de la Urbe. En efecto, ${ }^{*}$ Ruma es la ciudad de las ubres (y de las colinas), en donde el fundador Rómulo mamó de las de las tetas de la loba. Pero resulta cónsono con el origen itálico de los nombre de la ciudad y de su fundador el reconocer el aporte exterior de raíces culturales externas, a las que Roma se conecta con su inculturización etrusca durante la época de los Tarquinos, siglo vi a.C., y con la helenización que se opera a partir de los contactos habidos con la civilización griega tras la conquista de las ciudades del Sur de Italia y de la Magna Grecia durante los siglos IV y III a.C.

En primer lugar si, como ya el propio comentador Servio nos ponía en antecedentes, las dos ensenadas del río Tíber al pie del Palatino tenían forma de ubres, rumae, allí mismo donde la ciudad recibió el nombre *Ruma, no es sorprendente pensar que ya desde el inicio los etruscos pudieran asociar al río el nombre de la ciudad e interpretar Roma como la ciudad del Rumon. En tal caso, Rumon significa a la vez «río» y «ubre».

Y a tenor de la nueva situación que se crea a partir del s. vi a.C. es comprensible el exitoso intento greco-etrusco de inserir a Eneas en las raíces de Roma. Como la ciudad recibe nueva savia cultural etrusca y griega (esa es la Historia que aquí cuenta y no la letra de los mitos, que se limitan a reflejar la situación real), así Rómulo, el mítico fundador de Roma, recibe en su sangre, desde ahora mestiza, además del viejo aporte latino, el nuevo aporte troyano de su remoto antepasado Eneas - lo que para la monarquía etrusca de Tarquinio Prisco, personaje de origen corintio, significaba un aporte mixto greco-etrusco: Las ciudades de la Etruria meridional querían remontarse a Eneas, como demuestran las estatuillas de Eneas encontradas en Veyos, que reivindican el carácter propio de la ciudad (no hay por qué interpretarlas como de origen latino). Y en los Tarquinos fluye la sangre grecoetrusca -recuérdese la reivindicación, ahora demodée, del carácter anatolio de la raza etrusca. Helánico de Lesbos había querido hacer al aqueo Ulises padre del rey Latino. Cuando en la primera mital del s. vı a.C. «se aportan las primeras im- 
portantes correcciones, como Eneas abuelo de Rómulo» (Carandini 2002: 376), lejos de falsear le leyenda fundacional originaria, se la está reforzando, al poner las bases que llevan a conectar Roma con Rhome y a hacer de Roma sinónimo de Pळ $\mu \eta$,»fuerza». El paso de *Ruma a Roma queda así sólidamente fundamentado en la filología y en la historia ${ }^{49}$. Por su parte, la historia primitiva de Roma (el poblamiento de las colinas, el culto de Rumina, el rito fundacional de la Urbe...) queda fundida en el terreno de los hechos con la leyenda (Rómulo bajo las ubres de la loba...). En el mundo de los hechos, historia propiamente dicha y mito (en cuanto creencia «vivida») se combinan como territorios complementarios, antes que incompatibles.

Por eso, sobre todo, Ruma es la teoría actualmente preferible sobre el origen del nombre de Roma. Tiene como punto débil la carencia de un testimonio explícito que documente el nombre: mientras tanto Ruma consiste solamente en una verosímil hipótesis: * Ruma. Pero, mientras tanto, la teoría de que el nombre de Roma procede de Ruma es la que posee el mayor contenido informativo sobre cómo, cuándo y por qué se formó la Urbe.

La teoría Ruma tiene, en fin, el poder explicativo antecedente, que consiste en catalizar las tres teorías precedentes entre sí, y todas ellas con el relato canónico. La teoría Ruma aporta una nueva savia -filológica y arqueológica simultáneamente- al estudio de la Roma fundacional. Y, además, nos reconcilia con la imagen del primitivo Lacio, que medio siglo de teoría crítica (ahora demostradase fallida) había distorsionado. La hiper-crítica demoladora de la segunda mitad del siglo xx dejó indefensos a muchos amantes convictos de la leyenda fundacional de Roma, que se acogieron, desvalidos a la teoría etrusquizante del origen de la Urbe. Ahora, la teoría Ruma permite recuperar una visión de la fundación de Roma en la que el dato estrictamente histórico se puede conjugar con el relato mítico en una operación metodológica que la Antropología contemporánea avala en plenitud.

En sentido popperiano esta teoría es al menos una aproximación mayor a la verdad: Así como ella contiene las teorías 1 (Rhome) y 2 (Rumon) como un paso hasta 3 (Ruma), ella misma no excluye el no ser más que un paso adelante en orden a encontrar otra teoría que, al ser contrastada con 3 , se muestre preferible a ella y más cerca aún de la verdad.

49 Sin duda la teoría Ruma conjuga la filología con la arqueología, como bien reivindicaba Grandazzi, 1993, p.61. 